\title{
Medicinal Plant Species Used to Treat Tonsillitis in Ethiopia: A Systematic Review
}

\author{
Firew Bekele Abebe ${ }^{1}$, Melese Mengistu Asfaw ${ }^{2} \&$ Tasisa Temesgen Tolossa ${ }^{1}$ \\ ${ }^{1}$ College of Agriculture and Environmental Sciences, School of Natural Resources Management, Haramaya \\ University, Ethiopia \\ ${ }^{2}$ College of Agriculture and Environmental Sciences, School of Plant Sciences, Haramaya University, Ethiopia \\ Correspondence: Firew Bekele Abebe, School of Natural Resources Management and Environmental Sciences, \\ College of Agriculture and Environmental Sciences, Haramaya University, Ethiopia. Tel: 251-912-490-990. \\ E-mail: firewb12@gmail.com
}

Received: November 28, 2019

Accepted: February 28, $2020 \quad$ Online Published: March 4, 2020

doi:10.5539/jps.v9n1p34

URL: https://doi.org/10.5539/jps.v9n1p34

\begin{abstract}
In various areas of Ethiopia, different plant species have been reported having a medicinal role for ailment tonsillitis. However, the ethnomedicinal information on those medicinal plant species that cure the ailment is not summarized in a way that gives general information and initiates further study. Therefore, the objective of this review paper was to summarize the ethnomedicinal information about medicinal plant species that used to treat tonsillitis in Ethiopia. The result of the review indicated that herbs and leaves are the most utilized growth forms and part of the plants respectively during remedy preparation for the ailment tonsillitis in Ethiopia. Similarly, fresh plant materials, and water are the most applied condition of plant parts and diluent added correspondingly. Chewing and oral route of application are the most widely used methods of remedy preparation and administration correspondingly, for the ailment in the country. Utilization of herbs and leaves can be seen as an advantage from the conservation point of view of medicinal plant species that used to treat the ailment since herbs can be cultivated when they are in short supply and are also available as compared to other growth forms. Similarly, use of leaves can reduce damage to the medicinal plant species as compared to the use of other plant parts such as roots. However, the utilization of fresh materials should be reduced as much as possible. Rhamnus prinoides L'Hér. and Zingiber officinale Roscoe are the most commonly used medicinal plant species for the ailment in Ethiopia.
\end{abstract}

Keywords: ailment, conservation, growth form, remedy

\section{Introduction}

Ethnobotany is a scientific study of how peoples interact with plant resources within their ethnic groups. It gives particular emphasis on traditional cultures (Getaneh and Girma, 2014) and plays an important role in the discovery of new products from plants (Katewa, 2009). Plants provide a variety of use for every life form (Schippmann et al., 2002). Since ancient times they have been crucial sources of both defensive and remedial traditional medicine preparations for both human beings and livestock. (Ghanthi and Manickam, 2008; Lulekal et al., 2008; Zerabruk and Yirga, 2012).

Ethiopia is a country characterized by a wide range of ecological, climatic and edaphic conditions. Such a wide range of ecological, climatic and edaphic settings, makes the country an important regional center for biological diversity in terms of both fauna and flora (Kelbessa et al., 1992; Friis et al., 2011; Zerabruk and Yirga, 2012). Because of high biological diversity of flora, the country owns a wide range of potentially useful medicinal plants, wider indeed than available in many other areas of the world (Abebe, 1986). According to UNEP. (1995), Ethiopia is believed to be home for about 6,500 species of higher plants, with approximately $12 \%$ endemic plant species.

Starting from ancient time medicinal plants form the basis of traditional healthcare systems for the majority of the population of developing nations (Mesfin et al. 2014). Like many other developing nations, in Ethiopia, there is also a long history of using medicinal plants to treat a variety of ailments (Giday et al., 2009). Nearly 80\% of the country's population relies on traditional medicine to meet their health care needs (Bekele, 2007; Bekalo et 
al., 2009). The widespread use of traditional medicine could be attributed to cultural acceptability (Tesfaye et al., 2009), efficacy against certain types of diseases (Omoruyi et al., 2012), physical accessibility and affordability (Zerabruk and Yirga, 2012).

Tonsillitis is an inflammation of the tonsils (Alasmari et al., 2017; Bartlett et al., 2015). Cause of the ailment can be a viral or bacterial infection (Hibbert et al., 2019; Alasmari et al., 2017; Georgalas et al., 2009). According to Alasmari et al. (2017), tonsillitis most frequently occurs in children. Fever, sore throat, foul breath, difficulty in swallowing are some symptoms of the ailment.

Like other human ailments, there are modern treatments for tonsillitis such as providing antibiotics and surgery (tonsillectomy). However, these modern treatments, especially surgery, do have their own side effects and may cause death (Georgalas et al., 2009). Thus, there is a need to explore alternative therapies, particularly from plant sources as these are cost-effective and possess minimal side effects, and are also easily available.

In various areas of Ethiopia different plant species have been reported having a medicinal role for ailment tonsillitis (Chekole, 2017; Zenebe et al., 2012; Tegene, 2018; Tolossa et al., 2013). However, the ethnomedicinal information on medicinal plant species that cure the ailment is not summarized in a way that gives general information and initiates further study. Therefore, the objective of this review paper was to summarize the ethnomedicinal information available about medicinal plant species that used to treat tonsillitis in Ethiopia.

\section{Materials and Methods}

In order to generate data for the review, published research articles on ethnobotanical studies of medicinal plants in Ethiopia were collected. Among the collected studies, only those that provide ethnobotanical information on the ailment tonsillitis were used as a source of data for the review. Microsoft office excel 2016 was used to summarize all the information obtained using descriptive statistics and draw graphs.

\section{Medicinal Plants Reported}

Fifty-one medicinal plant species that belong to 31 families reported having a medicinal role for an ailment of tonsillitis (table 1). The families with the highest number of reported species were Fabaceae and Asteraceae (each consisting of 7 species) followed by Lamiaceae which contains 4 species (Figure 1A). 
Table 1. List of medicinal plant species used to treat tonsillitis

\begin{tabular}{|c|c|c|}
\hline No. & Species & Source \\
\hline 1 & $\begin{array}{l}\text { Cyphostemma adenocaule (Steud. Ex A. Rich.) } \\
\text { Desc. ex Wild \& R.B.Drumm. }\end{array}$ & Giday et al., 2016 \\
\hline 2 & Verbena officinalis L. & Giday et al., 2016 \\
\hline 3 & Otostegia fruticosa (Forssk.) Schweinf. Ex Penzig & Getaneh and Girma, 2014 \\
\hline 4 & Cynoglossum amplifolium Hochst. ex A.DC. & Birhan et al., 2018 \\
\hline 5 & Thunbergia alata Bojer ex Sims. & Birhan et al., 2018 \\
\hline 6 & Acmella caulirhiza Del. & $\begin{array}{l}\text { Tegene, 2018; } \\
\text { Maryo et al., } 2015\end{array}$ \\
\hline 7 & Schinus molle L. & Tegene, 2018; Birhanu et al., 2015 \\
\hline 8 & Zingiber officinale Roscoe & $\begin{array}{l}\text { Tegene, 2018; Temam \& Dillo, 2016; } \\
\text { Maryo et al., } 2015\end{array}$ \\
\hline 9 & Clematis longicauda Steud ex. A. Rich. & Ayele et al., 2015 \\
\hline 10 & Buddleja polystachya Fresen. & Meressa, 2018 \\
\hline 11 & Otostegia integrifolia Benth. & Meressa, 2018 \\
\hline 12 & Rhus retinorrhoea Oliv. & Chekole, 2017 \\
\hline 13 & Inula confertiflora A. Rich. & Chekole, 2017 \\
\hline 14 & Kalanchoe laciniata (L.) DC. & Chekole, 2017 \\
\hline 15 & Ajuga integrifolia Buch. -Ham. ex D. Don & Chekole, 2017 \\
\hline 16 & Rhamnus prinoides L'Hér. & $\begin{array}{l}\text { Chekole, 2017; Zenebe et al., 2012; } \\
\text { Birhanu et al., 2015; Gebeyehu et al., } 2014\end{array}$ \\
\hline 17 & Artemisia absinthium $\mathrm{L}$. & Chekole, 2017 \\
\hline 18 & Garcinia livingstonei $\mathrm{T}$. Anders & Birhanu and Haji, 2017 \\
\hline 19 & Rumex nepalensis Spreng. & Temam \& Dillo, 2016; Maryo et al., 2015 \\
\hline 20 & Solanum incanum $\mathrm{L}$. & Temam \& Dillo, 2016; Maryo et al., 2015 \\
\hline 21 & Vernonia amygdalina Del. & Temam \& Dillo, 2016 \\
\hline 22 & Acacia etbaica Schweinf. & Wondimu et al., 2007 \\
\hline 23 & Acacia nilotica (L.) Willd. ex. Del. & Wondimu et al., 2007 \\
\hline 24 & Acacia tortilis (Forssk.) Hayne & Wondimu et al., 2007 \\
\hline 25 & Leucas abyssinica (Benth.) Briq. & Wondimu et al., 2007 \\
\hline 26 & Senna occidentalis (L.) Link. & Mesfin et al., 2009; Bekele and Reddy, 2015 \\
\hline 27 & Lepidium sativum $\mathrm{L}$. & Zenebe et al., 2012 \\
\hline 28 & Ximenia americana $\mathrm{L}$. & Zenebe et al., 2012; Jima and Megersa,2018 \\
\hline 29 & Ziziphus spina-christi $\quad$ L. & Zenebe et al., 2012 \\
\hline 30 & Erythrina abyssinica Lam. ex DC. & Kebebew and Mohamed, 2017 \\
\hline 31 & Trichodesma zeylanicum (Burm.f.) R. Br. & Mengesha, 2016 \\
\hline 32 & Achyranthes aspera $\mathrm{L}$. & Tolossa et al., 2013; Yirga, 2010 \\
\hline 33 & Aframomum corrorima (Braun) Jansen & Maryo et al., 2015 \\
\hline 34 & Clematis longicauda Steud. ex A. Rich & Maryo et al., 2015 \\
\hline 35 & Dovyalis abyssinica (A. Rich.) Warb. & Maryo et al., 2015 \\
\hline 36 & Echinops kebericho Mesfin & Maryo et al., 2015 \\
\hline 37 & Juniperus procera Hochst. ex Endl. & Maryo et al., 2015 \\
\hline 38 & Lysimachia ruhmeriana Vatke & Maryo et al., 2015 \\
\hline 39 & Momordica foetida Schumach. & Maryo et al., 2015 \\
\hline 40 & Oxalis corniculata $\mathrm{L}$. & Maryo et al., 2015 \\
\hline 41 & Plantago lanceolata $\mathrm{L}$. & Maryo et al., 2015 \\
\hline 42 & Schefflera abyssinica (Hochst. ex A.Rich.) Harms & Maryo et al., 2015 \\
\hline 43 & Bersama abyssinica Fresen. & Giday et al., 2009 \\
\hline 44 & Microglossa pyrifolia (Lam.) O.Kuntze & Giday et al., 2009 \\
\hline 45 & Ritchiea albersii Gilg & Giday et al., 2009 \\
\hline 46 & Capparis tomentosa Lam. & Tefera and Kim, 2019 \\
\hline 47 & Carissa spinarum $\mathrm{L}$. & Regassa, 2013 \\
\hline 48 & Ricinus communis $\mathrm{L}$. & Regassa, 2013 \\
\hline 59 & Acacia pilispina Pic. -Serm. & Gebeyehu et al., 2014 \\
\hline 50 & Kalanchoe petitiana A. Rich. & Gebeyehu et al., 2014 \\
\hline 51 & Plumbago zeylanica $\mathrm{L}$. & Gebeyehu et al., 2014 \\
\hline
\end{tabular}




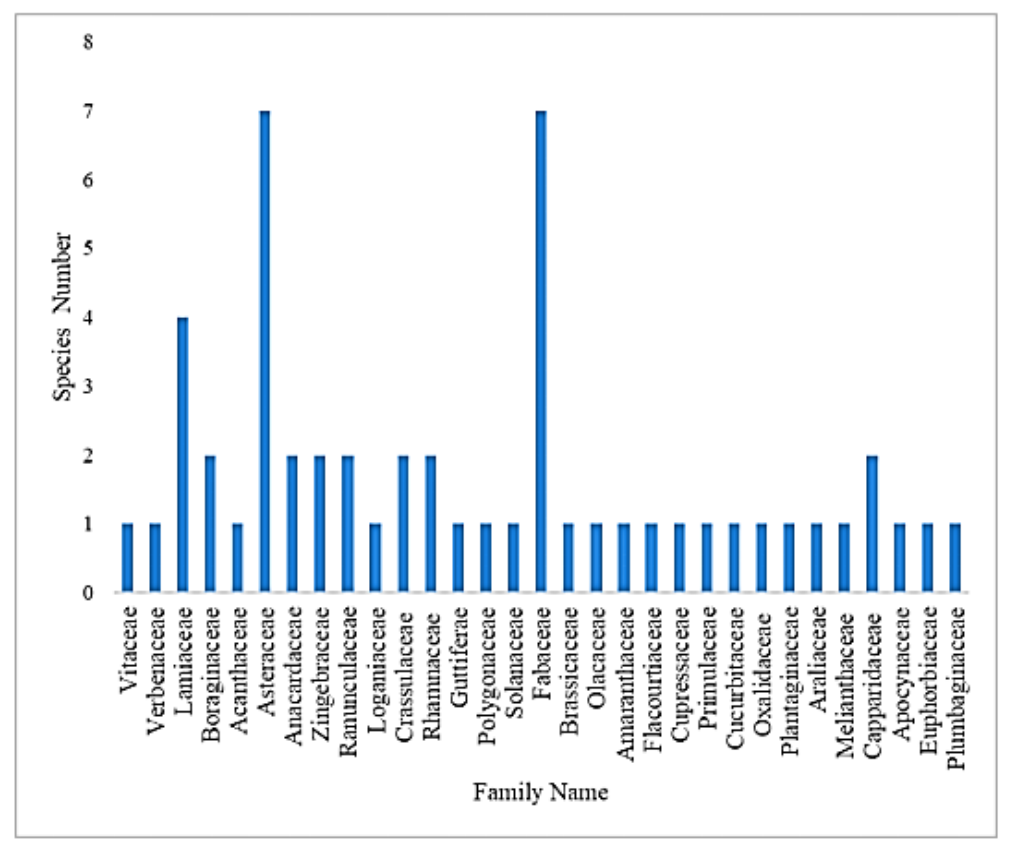

Figure 1. Families of medicinal plant species that used to treat tonsillitis

\section{Growth Forms and Parts of Medicinal Plant Species}

Analysis of the growth form of medicinal plants used to treat tonsillitis showed that herbs occupy the highest proportion $(42 \%)$ followed by trees $(31 \%)$, shrubs $(19 \%)$ and climbers $(8 \%)$ (Figure 2a). The highest use of herbaceous plants as compared to the other growth forms can be a result of their availability (Giday et al., 2009) or the higher possibility of obtaining pharmacologically active compounds in herbs as compared to the other growth forms (Thomas et al., 2009). The socio-cultural beliefs and practices of the healers in treating the ailment may also contribute to the high use of herbs (Abebe, 2019).

The plant parts used to treat tonsillitis include leaves, roots, fruits, flower, bark, seed and shoot tip (Figure $2 b$ ). The most commonly used plant parts for herbal preparations were leaves $(40 \%)$, followed by roots $(30.91 \%)$ and bark $(12.73 \%)$ (Figure 2b). Common utilization of leaves in the preparation of remedies can be a result of the relative easiness of finding this plant part as compared with the others (Getaneh and Girma, 2014).

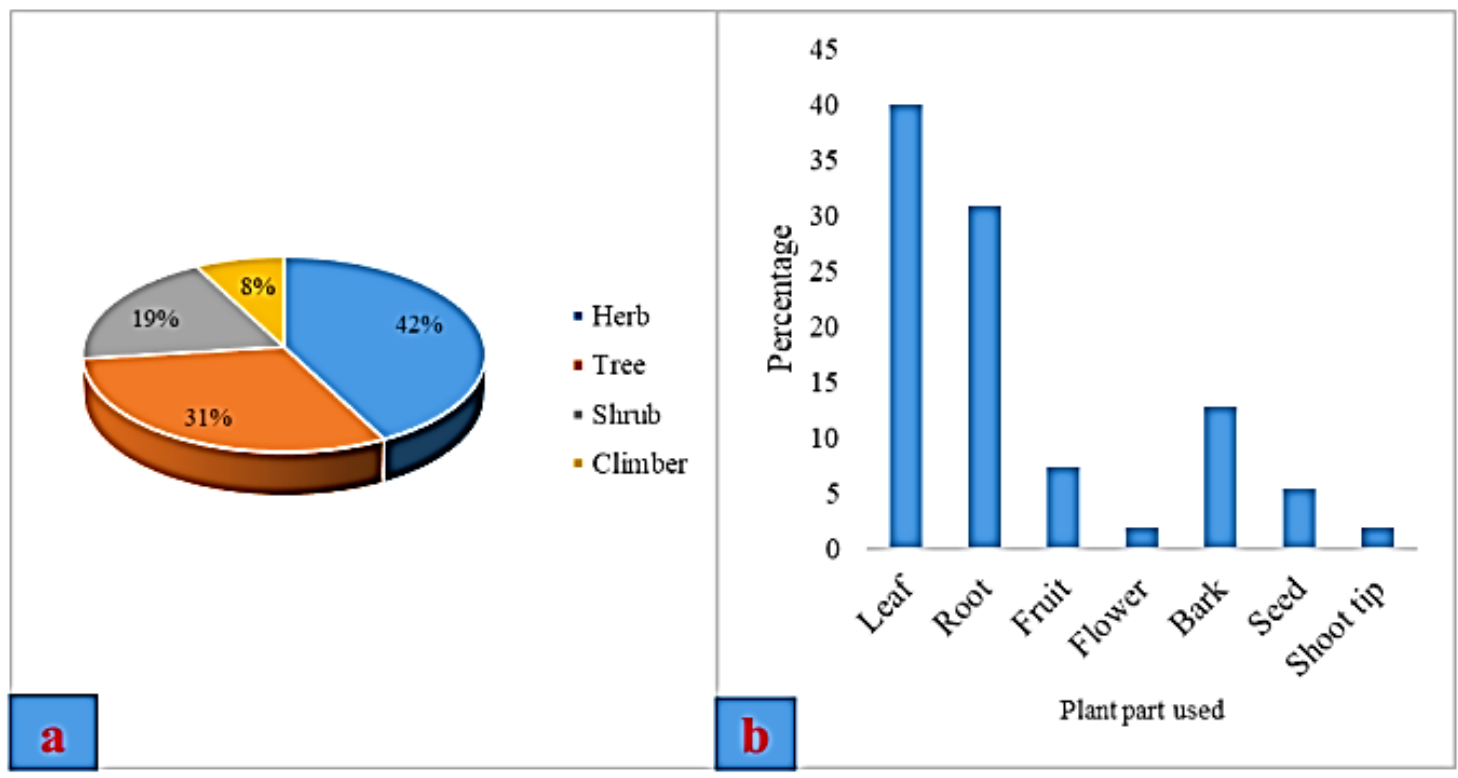

Figure 2. (A) Growth form, (B) Parts of medicinal plant species that used to treat tonsillitis 
Most of the remedies $(84.37 \%)$ which are used for an ailment of tonsillitis were prepared from fresh plant materials (Figure 3a). Some were prepared from dry parts $(9.37 \%)$ and the remaining others favorably from both fresh and dry plant materials $(6.25 \%)$. The highest use of fresh plant materials in the preparation of remedies can be due to the availability of plentiful plant materials around the healers or user's localities which can be picked at any time (Giday et al., 2009; Mesfin et al., 2014). The highest use of fresh materials can be also an effort not to lose volatile oils found in the plant materials (Mesfin et al., 2014). The belief of users or healers that fresh materials are effective in healing ailments can be the other reason for the highest use of these plant materials (Maryo et al., 2015).

The widely used methods of preparation of the remedies used for the ailment tonsillitis was chewing $(42.11 \%)$ followed by crushing (26.32\%). Other methods of remedy preparation that were used for ailment tonsillitis include squeezing, fumigating, boiling, and unprocessed each accounting $21.05 \%, 5.26 \%, 2.63 \%$, and $2.63 \%$ respectively (Figure 3b).

The majority of remedies $(71.06 \%)$ used to treat tonsillitis prepared without adding diluents. whereas some prepared by adding water $(23.68 \%)$, and few by adding butter (2.63\%) and tea (2.63\%) (Figure 3c). More use of water as compared to butter and tea in the preparation of remedies can be due to the relative ease of finding water (Giday et al., 2009). Its contribution to enhancing the efficacy and healing conditions of the remedies may also have attributed to its use (Abebe, 2019).

The common route administration of remedies for the ailment tonsillitis was oral $(89.1 \%)$ followed by nasal and dermal each accounting 5.45\% (Figure 3d). According to Abebe (2019), the selection of the route of administration of remedies is dependent on the ailment treated. Thus, the common use of oral administration of remedies during the treatment of tonsillitis is caused by the location of the ailment since tonsillitis occurs in the mouth.

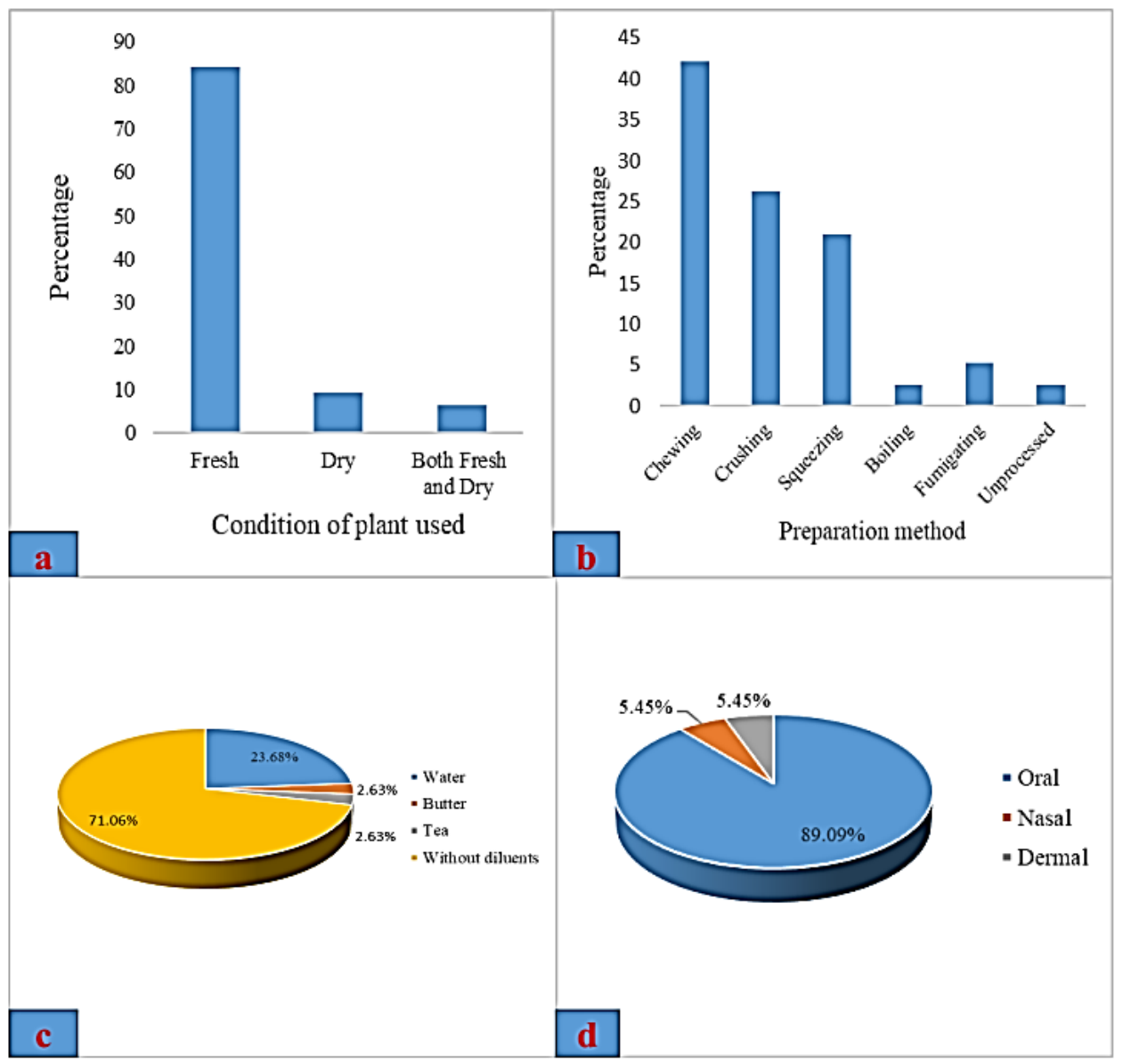

Figure 3. (A) Condition of plant part used, (B) Preparation method, (C) Diluents used, (D) Route of administration of medicinal plants used to treat tonsillitis 


\section{Common Plant Species Used To Treat Tonsillitis}

Plant species Rhamnus prinoides L'Hér, Zingiber officinale Roscoe, Acmella caulirhiza Del., Schinus molle L., Rumex nepalensis Spreng., Solanum incanum L. and Ximenia americana L. are the identified medicinal plant species which were used by traditional healers in more than one areas (different locations) within the country (Table 2). Accordingly, plant species Rhamnus prinoides L'Hér. and Zingiber officinale Roscoe are the first and second most common plant species that were used to treat tonsillitis in Ethiopia. The availability or efficacy of these medicinal plant species may have attributed to their common use.

Table 2. Commonly utilized plant species used to treat tonsillitis

\begin{tabular}{|c|c|c|c|c|}
\hline Species & $\begin{array}{l}\text { Name of areas in which } \\
\text { the species used to treat } \\
\text { tonsillitis }\end{array}$ & $\begin{array}{l}\text { Number } \\
\text { of areas }\end{array}$ & $\begin{array}{l}\text { Species Rank (Based } \\
\text { on the number of areas } \\
\text { in which the species } \\
\text { used to treat tonsillitis) }\end{array}$ & Source \\
\hline $\begin{array}{l}\text { Zingiber } \\
\text { officinale } \\
\text { Roscoe } \\
\text { Rhamnus } \\
\text { prinoides } \\
\text { L'Herit. }\end{array}$ & $\begin{array}{l}\text { Bale Zone; Hadiya Zone; } \\
\text { Kembatta Tembaro (KT) } \\
\text { Zone } \\
\text { North Wollo Zone; } \\
\text { Asgede Tsimbila District, } \\
\text { Tigray Region; Wollega } \\
\text { Zone; West Gojjam Zone }\end{array}$ & 4 & 2 & $\begin{array}{l}\text { Tegene, 2018; Temam \& } \\
\text { Dillo, 2016; Maryo et al., } \\
\text { 2015 } \\
\text { Chekole, 2017; } \\
\text { Zenebe et al., 2012; } \\
\text { Birhanu et al., 2015; } \\
\text { Gebeyehu et al., } 2014\end{array}$ \\
\hline $\begin{array}{l}\text { Acmella } \\
\text { caulirhiza Del. } \\
\text { Schinus molle } \\
\text { L. }\end{array}$ & $\begin{array}{l}\text { Bale Zone; Kembatta } \\
\text { Tembaro (KT) Zone } \\
\text { Bale Zone; Wollega Zone }\end{array}$ & 2 & 3 & $\begin{array}{l}\text { Tegene, 2018; } \\
\text { Maryo et al., } 2015 \\
\text { Tegene, 2018; } \\
\text { Birhanu et al., } 2015\end{array}$ \\
\hline $\begin{array}{l}\text { Rumex } \\
\text { nepalensis } \\
\text { Spreng. }\end{array}$ & $\begin{array}{l}\text { Hadiya Zone; Kembatta } \\
\text { Tembaro (KT) Zone }\end{array}$ & 2 & 3 & $\begin{array}{l}\text { Temam \& Dillo, 2016; } \\
\text { Maryo et al., } 2015\end{array}$ \\
\hline $\begin{array}{l}\text { Solanum } \\
\text { incanum } \mathrm{L} \text {. }\end{array}$ & $\begin{array}{l}\text { Hadiya Zone; Kembatta } \\
\text { Tembaro (KT) Zone }\end{array}$ & 2 & 3 & $\begin{array}{l}\text { Temam \& Dillo, 2016; } \\
\text { Maryo et al., } 2015\end{array}$ \\
\hline $\begin{array}{l}\text { Ximenia } \\
\text { americana } \mathrm{L} \text {. }\end{array}$ & $\begin{array}{l}\text { Asgede } \\
\text { Tigrimbila District, } \\
\text { Zone; }\end{array}$ & 2 & 3 & $\begin{array}{l}\text { Zenebe et al., 2012; } \\
\text { Jima and Megersa, } 2018\end{array}$ \\
\hline $\begin{array}{l}\text { Achyranthes } \\
\text { aspera } \mathrm{L} .\end{array}$ & $\begin{array}{lr}\text { South } & \text { Omo; } \quad \text { Endrta } \\
\text { District, } & \text { South-eastern } \\
\text { Tigray } & \end{array}$ & 2 & 3 & $\begin{array}{l}\text { Tolossa et al., 2013; Yirga, } \\
2010\end{array}$ \\
\hline
\end{tabular}

\section{Conclusion}

From the result of the review, it can be concluded that herbs and leaves are the most utilized growth forms and part of the plants respectively during remedy preparation for the ailment tonsillitis in Ethiopia. Similarly, fresh plant materials, and water are the most applied condition of plant parts and diluent added respectively. Chewing and oral application are the most widely used methods of remedy preparation and administration correspondingly, for the ailment in the country. Utilization of herbs and leaves can be seen as an advantage from the conservation point of view of medicinal plant species that used to treat the ailment since herbs can be cultivated when they are in short supply and are also more commonly available as compared to other growth forms. Similarly, the use of leaves can reduce damage to these medicinal plants as compared to other plant parts like roots. However, the use of fresh plant materials should be reduced as much as possible (for example people can reduce their dependence on fresh materials by using only dry materials, for those medicinal plant species that can be used in both fresh and dry forms) since their use may contribute to the over utilization of the medicinal plant species. Rhamnus prinoides L'Hér. and Zingiber officinale Roscoe are the most commonly used plant species for the treatment of tonsillitis in Ethiopia.

\section{Acknowledgments}

We would like to acknowledge Haramaya University for covering the publication fee of this review paper. We are also grateful to all who contribute during manuscript preparation. 


\section{References}

Abebe, D. (1986). Traditional medicine in Ethiopia. The attempt being made to promote it for effective and better utilization. SINET: Ethiopian Journal of Science, 9, 61-69.

Abebe, F. B. (2019). Ethnobotanical Studies of Medicinal Plants used to Treat Human and Livestock Ailments in Southern Nations, Nationalities and Peoples' Region, Ethiopia: A Systematic Review. Journal of Plant Studies, 8(1), 1-9. https://doi.org/10.5539/jps.v8n1p1

Alasmari, N. S. H., Bamashmous, R. O. M., Alshuwaykan, R. M. A., Alahmari, M. A. M., Almubarak, R. M., Alshahrani, A. A. M., ... Alamri, S. O. R. (2017). Causes and Treatment of Tonsillitis. The Egyptian Journal of Hospital Medicine, 69(8), 2975-2980. https://doi.org/10.12816/0042838

Ayele, T. T., Regasa, M. B., \& Delesa, D. A. (2015). Evaluation of Antimicrobial Activity of Some Traditional Medicinal Plants and Herbs from Nekemte District against Wound Causing Bacterial Pathogens. Science, Technology, and Arts Research Journal, 4(2), 199-203. http://dx.doi.org/10.4314/star.v4i2.24

Bartlett, A., Bola, S., \& Williams, R. (2015). Acute tonsillitis and its complications: an overview. Journal of the Royal Naval Medical Service, 101(1), 69-73.

Bekalo, T. H., Woodmatas, S. D., \& Woldemariam, Z. A. (2009). An ethnobotanical study of medicinal plants used by local people in the lowlands of Konta Special Woreda, southern nations, nationalities and people's regional state, Ethiopia. Journal of Ethnobiology and Ethnomedicine, 5, 26. https://doi.org/10.1186/1746-4269-5-26

Bekele, E. (2007). Study on actual Situation of Medicinal Plants in Ethiopia.

Bekele, G., \& Reddy, P. R. (2015). Ethnobotanical Study of Medicinal Plants Used to Treat Human Ailments by Guji Oromo Tribes in Abaya District, Borana, Oromia, Ethiopia. Universal Journal of Plant Science, 3(1), $1-8$.

Birhan, Y. S., Kitaw, S. L., Alemayehu, Y. A., \& Mengesha, N. M. (2018). Ethnobotanical study of medicinal plants used to treat human diseases in Enarj Enawga District, East Gojjam Zone, Amhara Region, Ethiopia. SM Journal of Medicinal Plant Studies, 2(1), 1006. https://doi.org/10.36876/smjmps.1006

Birhanu, A., \& Haji, F. (2017). Ethnobotanical Study of Medicinal Plants Used for the Treatment of Human and Livestock Ailments in Dawe Kachen District of Bale Zone, Southeast Ethiopia. International Journal of Emerging Trends in Science and Technology, 4(4), 5043-5055. https://doi.org/10.18535/ijetst/v4i4.01

Birhanu, T., Abera, D., \& Ejeta, E. (2015). Ethnobotanical Study of Medicinal Plants in Selected Horro Gudurru Woredas, Western Ethiopia. Journal of Biology, Agriculture and Healthcare, 5(1), 83-93.

Chekole, G. (2017). Ethnobotanical study of medicinal plants used against human ailments in Gubalafto District, Northern Ethiopia. Journal of Ethnobiology and Ethnomedicine, 13, 55. https://doi.org/10.1186/s13002-017-0182-7

Friis, I., Demissew, S., \& van Breugel, P. (2011). Atlas of the potential vegetation of Ethiopia. Addis Ababa University Press and Shama Books.

Gebeyehu, G., Asfaw, Z., Enyew, A., \& Raja, N. (2014). Ethnobotanical Study of medicinal plants and their Conservation Status in Mecha Wereda, West Gojjam Zone of Ethiopia. International Journal of Pharmaceuticals and Health Care Research, 2(3), 137-154.

Georgalas, C.C., Tolley, N.S. \& Narula, A. (2009). Tonsillitis. Clinical Evidence, 10, 503.

Getaneh, S., \& Girma, Z. (2014). An ethnobotanical study of medicinal plants in Debre Libanos Wereda, Central Ethiopia. African Journal of Plant Science, 8(7), 366-379. https://doi.org/10.5897/AJPS2013.1041

Ghanthi, K. S., \& Manickam, V. S. (2008). Ethnobotanical Utilization of Poecilineron pauciflorum Bedd. by the Kani Tribes of Agasthiamalai, Western Ghats, Tamil Nadu, India. Ethnobotany. Leaflets, 12, 719-722.

Giday, K., Lenaerts, L., Gebrehiwot, K., Yirga, G., Verbist, B., \& Muys, B. (2016). Ethnobotanical study of medicinal plants from degraded dry Afromontane forest in northern Ethiopia: Species, uses and conservation challenges. Journal of Herbal Medicine, 6, 96-104. http://dx.doi.org/10.1016/j.hermed.2016.03.004

Giday, M., Asfaw, Z., Woldu, Z., \& Teklehaymanot, T. (2009). Medicinal plant knowledge of the Bench ethnic group of Ethiopia: an ethnobotanical investigation. Journal of Ethnobiology and Ethnomedicine, 5(1), 34. https://doi.org/10.1186/1746-4269-5-34 
Hibbert, P., Stephens, J. H., Wet, C., Williams, H., Hallahan, A., Wheaton, G. R., Dalton, C., Ting, H. P., Arnolda, G., \& Braithwaite, J. (2019). Assessing the Quality of the Management of Tonsillitis among Australian Children: A Population-Based Sample Survey. Otolaryngology- Head and Neck Surgery, 160(1), 137-144. https://doi.org/10.1177/0194599818796137

Jima, T. T., \& Megersa. M. (2018). Ethnobotanical Study of Medicinal Plants Used to Treat Human Diseases in Berbere District, Bale Zone of Oromia Regional State, southeast Ethiopia. Evidence-Based Complementary and Alternative Medicine. https://doi.org/10.1155/2018/8602945

Katewa, S. S. (2009). Indigenous people and forests: Perspectives of an ethnobotanical study from Rajasthan (India). In Herbal Drugs: Ethnomedicine to modern medicine (pp.33-56). Springer, Berlin, Heidelberg. https://doi.org/10.1007/978-3-540-79116-4_3

Kebebew, M., \& Mohamed, E. (2017). Indigenous knowledge on use of medicinal plants by indigenous people of Lemo district, Hadiya zone, Southern Ethiopia. International Journal of Herbal Medicine, 5, 124-35.

Kelbessa, E., Demissew, S., Woldu, Z., \& Edwards, S. (1992). Some threatened endemic plants of Ethiopia. In Edwards, S., \& Asfaw, Z. (Eds). The status of Some Plants in Parts of Tropical Africa (pp. 35-55), Botany 2000: NAPREC, Monograph Series No.2. Addis Ababa University.

Lulekal, E., Kelbessa, E., Bekele, T., \& Yineger, H. (2008). An ethnobotanical study of medicinal plants in Mana Angetu District, southeastern Ethiopia. Journal of Ethnobiology and Ethnomedicine, 4, 10. https://doi.org/10.1186/1746-4269-4-10

Maryo, M., Nemomissa, S., \& Bekele, T. (2015). An ethnobotanical study of medicinal plants of the Kembatta ethnic group in the Enset-based agricultural landscape of KembattaTembaro (KT) Zone, Southern Ethiopia. Asian Journal of Plant Science and Research, 5(7), 42-61.

Mengesha, G. G. (2016). Ethnobotanical survey of medicinal plants used in treating human and livestock health problems in Mandura Woreda of Benishangul Gumuz, Ethiopia. Advancement in Medicinal Plant Research, $4(1), 11-26$.

Meressa, M. G. (2018). Traditional Medicinal Plants Used in Some selected kebeles of Woreda Ganta-Afeshum, Eastern Zone of Tigray Region, North Ethiopia. International Journal of Engineering Development and Research, 6(1), 483-487.

Mesfin, F., Demissew, S., \& Teklehaymanot, T. (2009) An ethnobotanical study of medicinal plants in Wonago Woreda, SNNPR, Ethiopia. Journal of Ethnobiology and Ethnomedicine, 5, 28. https://doi.org/10.1186/1746-4269-5-28

Mesfin, F., Seta, T., \& Assefa, A. (2014). An Ethnobotanical Study of Medicinal Plants in AmaroWoreda, Ethiopia. Ethnobotany Research and Applications, 12, 341-354. https://doi.org/10.17348/era.12.0.341-354

Omoruyi, B. E., Bradley, G., \& Afolayan, A. J. (2012). Ethnomedicinal survey of medicinal plants used for the management of HIV/AIDS infection among local communities of Nkonkobe Municipality, Eastern Cape, South Africa. Journal of Medicinal Plants Research, 6(19), 3603-3608. https://doi.org/10.5897/JMPR12.541

Regassa, R. (2013). Diversity and conservation status of some economically valued indigenous medicinal plants in Hawassa College of Teacher Education Campus, Southern Ethiopia. International Journal of Advanced Research, 1(3), 308-328. https://doi.org/10.5897/jmpr012.1126

Schippmann, U., Leaman, D. J., \& Cunningham, A. B. (2002). Impact of cultivation and gathering of medicinal plants on biodiversity: global trends and issues. Biodiversity and the ecosystem approach in agriculture, forestry, and fisheries.

Tefera, B. N., \& Kim, Y. D. (2019). Ethnobotanical study of medicinal plants in the Hawassa Zuria District, Sidama Zone, Southern Ethiopia. Journal of Ethnobiology and Ethnomedicine, 15, 25. https://doi.org/10.1186/s13002-019-0302-7

Tegene, A. S. (2018). An Ethnobotanical Study of Traditionally Used Medicinal Plants for Treatment of Human Diseases in Goba District of Bale Zone, Southeast Ethiopia. Advances in Life Science and Technology, 68.

Temam, T., \& Dillo, A. (2016). Ethnobotanical study of medicinal plants of Mirab-Badwacho district, Ethiopia. Journal of Bioscience and Biotechnology, 5(2), 151-158.

Tesfaye, H., Sebsebe, D., \& Zemede, A. (2009). An ethnobotanical study of medicinal plants used by local people in the lowlands of Konta Special Woreda, southern nations, nationalities and people's regional state. 
Ethiop. Journal of Ethnobiology and Ethnomedicine, 5, 26. https://doi.org/10.1186/1746-4269-5-26

Thomas, E., Vandebroek, I., Sanca, S., \& Van Damme, P. (2009). Cultural significance of medicinal plant families and species among the Quechua farmers in apillampampa, Bolivia. Journal of Ethnopharmacology, 122, 60-67. https://doi.org/10.1016/j.jep.2008.11.021

Tolossa, K., Debela, E., Athanasiadou, S., Tolera, A., Ganga, G., \& Houdijk, J. G. (2013). Ethno-medicinal study of plants used for treatment of human and livestock ailments by traditional healers in South Omo, Southern Ethiopia. Journal of Ethnobiology and Ethnomedicine, 9(1), 32. https://doi.org/10.1186/1746-4269-9-32

UNEP (United Nations Environment Program). (1995). Global Biodiversity Assessment. United Nations Environment Program, Nairobi, Kenya.

Wondimu, T., Asfaw, Z., \& Kelbessa, E. (2007). Ethnobotanical study of medicinal plants around 'Dheeraa' town, Arsi Zone, Ethiopia. Journal of Ethnopharmacology, 112, 152-161.

https://doi.org/10.1016/j.jep.2007.02.014

Yirga, G. (2010). Assessment of traditional medicinal plants in Endrta District, South-eastern Tigray, Northern Ethiopia. African Journal of Plant Science, 4(7), 255-260.

Zenebe, G., Zerihun, M., \& Solomon, Z. (2012). An Ethnobotanical Study of Medicinal Plants in Asgede Tsimbila District, Northwestern Tigray, Northern Ethiopia. Ethnobotany Research \& Applications, 10, 305-320. https://doi.org/10.17348/era.10.0.305-320

Zerabruk, S., \& Yirga, G. (2012). Traditional knowledge of medicinal plants in Gindeberet district, Western Ethiopia. South African Journal of Botany, 78, 165-169. https://doi.org/10.1016/j.sajb.2011.06.006

\section{Copyrights}

Copyright for this article is retained by the author(s), with first publication rights granted to the journal.

This is an open-access article distributed under the terms and conditions of the Creative Commons Attribution license (http://creativecommons.org/licenses/by/4.0/). 